\title{
THE STAGES OF THE DECLINE OF THE PUBLIG/PRIVATE DISTINCTION
}

\section{Duncan Kennedy $\dagger$}

Success for a legal distinction has two facets. First, it must be possible to make the distinction: people must feel that it is intuitively sensible to divide something between its poles, and that the division will come out pretty much the same-way regardless of who is doing it. Second, the distinction must make a difference: a distinction without a difference is a failure even if it is possible for everyone to agree every time on how to make it. Making a difference means that it seems plain that situations should be treated differently depending on which category of the distinction they fall into.

When people hold a symposium about a distinction, it seems almost certain that they feel it is no longer a success. Either people can't tell how to divide situations up between the two categories, or it no longer seems to make a difference on which side a situation falls.

The history of legal thought since the turn of the century is the history of the decline of a particular set of distinctions-those that, taken together, constitute the liberal way of thinking about the social world. ${ }^{1}$ Those distinctions are state/society, public/ private, individual/group, right/power, property/sovereignty, contract/tort, law/policy, legislature/judiciary, objective/subjective, reason/fiat, freedom/coercion, and maybe some more I'm not thinking of. Although these distinctions are not synonymous, they are all in a sense "the same." By this I mean that it is hard to define any one of them without reference to all, or at least many of the others, and that if one understands the common usage of one of them, one understands, pretty much ipso facto (what a fudge!), all the others.

Because all the distinctions that constitute the liberal mode have gone through at least analogous processes of.decline, it should be possible to say something in a general way about the later stages

† Professor of Law, Harvard University. B.A. 1964, Harvard University; LL.B. 1970, Yale University.

1 See Kennedy, The Structure of Blackstone's Commentaries, 28 Bufrato L. REv. 205, 209-21, 258-61, 286-300, 354-62 (1979); see also Gordon, New Developments in Legal Theory, in THE PoLrrics of LAW 281 (D. Kairys ed. 1982); Mensch, The History of Mainstream Legal Thought, in id. 18. 
of the life history of the group, but so far as I know no one has yet attempted this task. - What I offer here, writing under the influence of Al Katz, Mark Kelman, and Fran Olsen, ${ }^{2}$ is a crude set of guesses about what such an historical enterprise might turn up. I suggest that there is an invariant sequence of six stages in a distinction's passage from robust good health to utter decrepitude. I will use the public/private distinction to illustrate each stage.

\section{Hard Cases with Large Stakes}

While a distinction is still in its heyday, there arise cases about which people disagree passionately, and on whose resolution those same people believe a great deal turns. For example, in Osborn v. Bank of the United States, ${ }^{3}$ a state official had seized the assets of the Bank of the United States and the Bank was suing him to get them back. The eleventh amendment prohibited suits in federal court against the states. Everyone agreed that you could sue the state official if he murdered someone (and the federal courts had some basis of jurisdiction) in spite of the eleventh amendment, and everyone agreed that the eleventh amendment would bar a suit in federal court to force the officer to perform a ministerial duty under state law. But this case was tricky: it "fell in between." Doubly tricky, because it also raised the question whether the Bank of the United States was a public or a private institution. ${ }^{4}$ The stakes were high because the legality of the Bank was a big political issue, as was the relationship between the federal and state governments, as was the relationship between the Whig/Federalist judiciary and the Jacksonian executive branch of the federal government. ${ }^{5}$

Hard cases with large stakes engage peoples' energies in the task of manipulating the distinction, analyzing it, fretting about it. Hard cases are a sign of health, but they are also an indication that there may be trouble ahead. The trouble begins with:

2 A. Katz, Studies in Boundary Theory (pt. I): Six Essays on Crime and Criminal Law (1980) (unpublished manuscript) (copy on file with University of Pennsylvania Law Review); Katz, Studies in Boundary Theory: Three Essays in Adjudication and Politics, 28 Buffalo L. Rev. 383 (1979); Kelman, Interpretive Construction in the Substantive Criminal Law, 33 Stan. L. REv. 591 (1981); Olsen, The Family and the Market: A Study of Ideology and Legal Reform (forthcoming in 96 Harv. L. Rev., Spring 1983).

322 U.S. (9 Wheat.) 738 (1824).

4 Id. 859-61.

5 See A. Sutherland, Constitutronalism in America 370-73 (1965); C. Swisher, American Constitutional Development 177-85 (2d ed. 1954). 


\section{The Development of Intermediate Terms}

The development of intermediate terms means formal recognition that some situations are neither one thing nor anotherneither public nor private-but rather share some characteristics of each pole, as in the case of private businesses affected with a public interest (the grain elevators in Munn $v$. Illinois ${ }^{6}$ ). Another example is a governmental entity wholly engaged in a "proprietary activity," 7 and another would be a private entity engaged in a "governmental function," such as the owner of the company town in Marsh v. Alabama.

The development of intermediate terms is likely to be important for two different reasons. First, it probably represents the emergence of serious conflict about how to characterize a large number of hard cases with large stakes, as well as a sense on the part of the deciding people that they can't just come down cleanly on one side or the other. Consensus about categorization begins to break down. Second, it probably means that it is becoming more difficult to decide what difference it makes how we categorize a situation. The intermediate entity gets treated "as though" it were public for some purposes, and "as though" it were private for other purposes. This means not only that the institution in question "falls on the line," but also that the responses that used to follow, à la Pavlov, when I said public or you said private, begin to lose their all-or-nothing, set-like quality.

\section{Collapse}

An important and exciting moment in the history of a distinction arrives when troublemakers begin to argue that the distinction is incoherent because, no matter how you try to apply it, you end up in a situation of hopeless contradiction. The form of this argument is likely to be as follows: you say that something is $X$ if it has property $A$, and that it is $Y$ if it has property $B$. But everything has property $A$, so everything is $X$, and the distinction between $X$ and $Y$ has collapsed.

Some fun examples of this involve the public/private distinction. Morris Cohen argued that because both property rights and contract rights were enforced by the state, the so-called rights were

694 U.S. $113,126-34$ (1877).

7 See Ellickson, Cities and Homeowners Associations, 130 U. PA. L. REv. 1519, 1570-71 (1982) (citing examples).

8326 U.S. 501 (1946). 
really better conceived as delegated public powers, whose exercise should be subject to the rules of public accountability we associate with legislators, rather than with the rules of private accountability we associate with-what else? - property and contract. ${ }^{9}$

Another version of the same argument appears in an article by Robert Hale. ${ }^{\mathbf{1 0}}$ Because the government uses force to guarantee respect for private property, and property determines the distribution of income, the "free" "private" market is really an artifact of public violence. Louis Jaffe wrote an article called Law Making by Private Groups ${ }^{11}$ to show that the National Recovery Act Codes should have been upheld. So what if they involved massive delegation of lawmaking power to private cartels? Jaffe argued that it was still less delegation than was implicit in the quintessentially private institutions of the common law.

In Shelley v. Kraemer ${ }^{12}$ this collapsing tactic succeeded so well that it failed. If state enforcement of the property and contract groundrules of the market was "state action" for fourteenth amendment purposes, then the fourteenth amendment required the states to outlaw any "private" actor who practiced racial discrimination. As seems to happen regularly in the collapsing mode, the extreme consequences that arguably follow from abolition of the distinction lead people to pull back and resort to:

\section{Continuumization}

Continuumization means that people see most entities (institutions, actors, actions) as "not absolutely one thing or another," rather than reserving this status for a small class of intermediate terms, or collapsing everything into one pole or the other. With the exception of polar situations-passing laws or deciding lawsuits representing the "public" extreme, choosing a toothpaste or making love representing the "private" extreme-everything is "somewhere in the middle." However, it seems intuitively fairly easy to range the things in the middle along a continuum.

Continuumization seems to go along with the disaggregation of the package of legal responses that once seemed to follow "logi-

9 See M. CoHEN, Property and Sovereignty and The Basis of Contract, in LAW AND THE SOCIAL ORDER 41 and 69, 102 (1933); see also Brest, State Action and Liberal Theory: A Casenote on Flagg Brothers v. Brooks, 130 U. PA. L. REv. 1296, 1326-29 (1982).

10 Hale, Coercion and Distribution in a Supposedly Non-Coercive State, 38 Pox. Scr. Q. 470 (1923).

1151 Harv. L. REv. 201, 211-21 (1937).

12334 U.S. 1 (1948). 
cally" from the choice to categorize an institution one way or another. Institutions in the middle should have rules that are $a$ mixture of public and private modes: for example, sewer districts should have to observe the constitutional prohibition against tak: ings without just compensation but not the constitutional requirement of one-person/one-vote. ${ }^{13}$ In continuum consciousness, the ideal is a range of legal responses exactly calibrated to the range of fact situations: an overlay of one continuum on the other.'

People who believe in continua tend to explain how they go about deciding what legal response is appropriate for a given institution by listing "factors" that "cut" one way or the other and must be "balanced." The imagery of balancing fits the imagery of continua because balancing is an affair of fine quantitative gradations, rather than of the qualitative "absolutes" that were discredited during the stage of Collapse. There is now more room for disagreement, both about how to make the distinction and about what difference it should make, than there was in an earlier "simpler" time. But what looked for a moment like abolition or transcendence of the distinction during Collapse, turns out not to have happened. The distinction is dead, but it rules us from the grave.

\section{Stereotypification}

The last two stages in the history of the liberal distinctions are playing themselves out in our own present. They involve the dissolution rather than the collapse of distinctions, and the relaxation of the iron grip they exert from six feet under.

Stereotypification means that people come to see the overt, formally rational part of the argument about where an institution fits on the continuum, and about what mixed package of rules of procedure it should operate under, as involving the mechanical manipulation of balanced, pro/con policy arguments that come in matched pairs.

When the City of Detroit decides to condemn the whole Poletown neighborhood and then virtually gives it to an auto company as a plant site, there is a big argument about whether or not this is a taking for a "public" or a "private" purpose. ${ }^{14}$ Don't you feel,

13 Șee alṣo Ellickson, supra note 7, at $1542-43$ \& n.95 (discussing cases).

14 See Poletown Neighborhood Council v. City of Detroit, 410 Mich. 616, 304 N.W.2d 455 (1981); see also Crosby v. Young, 512 F. Supp. 1363 (E.D. Mich. 1981) (environmental litigation aspect of Poletown case). 
dear reader, a sensation of ennui, even of sleepiness, at the thought that I might actually tell you what they said? It's not just that the arguments are obvious. It's worse than that. The arguments deployed by Detroit in support of the publicness of this venture could be deployed in support of virtually any venture one can imagine. If, on the other hand, we take seriously the arguments against publicness deployed by the lawyers for Poletown, it is hard to imagine anything except a courthouse that would justify a taking.

In a sense, stereotypification is the working out, in the reassuring context of continua, of the practical implications of Collapse. "Legal" arguments prove too much: it just can't be the force of the formulae we use that causes our conviction that one side or the other. is right, since.we reject the identical arguments in the next case. And we have no meta-principle of appropriateness that will tell us when argument $A$ is right or when, on the contrary, it is flat wrong and $B$ is right. When a distinction reaches this stage, using it in legal argument seems a mere exercise: we can do it so well we can't believe in it any more.

\section{Loopification}

Loopification is the most interesting (to me) of all the stages, because it is somewhat hypothetical. I'm quite convinced that there is something to my description of stages one through five, but six is more of an attempt to guess why some of us find legal thought so freakily inadequate. One's consciousness is loopified when the ends of the continuum seem closer to one another, in some moods (for some purposes, in some cases), than either end seems to the middle. Otherwise stated, one's consciousness is loopified when one seems to be able to move by a steady series of steps around the whole distinction, ending up where one started without ever reversing direction. Like wow, man.

In the case of the public/private distinction, loopification occurs when one realizes that the private sector includes both the market and the family. We often conceive the family in terms very much like those we apply to the state, and treat the family as a domain "affected with a public interest" to the very extent that it is intensely private. "Likewise, we tend to understand the transactions of individual consumers, investors, tenants, and clients as more private than those of large or small businesses, but at the same time conceive of these individual transactions as more, rather than less, amenable to public regulation. All of this produces the following diagram, meant to be representative of the: 
Loopification of the Public/Private Distinction: .

Very large

corporations

Lawyers/doctors

Labor unions

Public utilities

Port authorities -

School boards

Local government

with home rule

Legislators

Judges

Executives
Small

businesses

Individual workers

Consumers

Investors

Tenants

Clients

Churches

Married persons

Parents

My assertion about this diagram is that you can move around it in a clockwise direction starting at the bottom with the classic state functionaries-legislators, judges, executives-and ending up with parents, feeling as you go that you are always moving in the direction of greater "privateness." Yet at the same time there is a sense in which the sequence eventually brings you back to where you began.

One ends up where one began because of all the ways in which we think of the family and the political community as close together rather than far apart. ${ }^{15}$ First, there are many analogies between them. They are both "units of government," rather than markets (though some law and economics types have recently argued for

15 What follows is heavily indebted to Olsen, supra note 2. My emphasis is on the meeting of the ends of the continuum rather than on the oddly public/private nature of modern labor and consumer transactions. On labor, see Klare, The Public/Private Distinction in Labor Law, 130 U. PA. L. REv. 1358 (1982); on consumers, see Kennedy, Distributive and Paternalist Motives in Contract and Tort Law, with Special References to Compulsory Terms and Unequal Bargaining Power, 41 MD. L. REv. 563 (1982). 
seeing them otherwise). ${ }^{18}$ Within them, actors play roles-occupy offices or statuses-which are fiduciary. There are lots of duties and lots of discretion, but neither the duty nor the discretion is like that of market actors. In the family and in the state, we tend to feel that overarching ideals ought to inform every decision, while we conceive the market actor as "free to do whatever she wants so long as she obeys the groundrules."

Second, political philosophy refers constantly to the ideals of the family, and philosophers of the family refer constantly to political ideals. The interpenetration of the two realms of discourse is so thorough that we might better speak of a single political/familial rhetoric. We use the market concept of consent or voluntariness only in a qualified, metaphorical, or "implied" sense in state and family. We temper the notion that you get what you paid for with natural law, natural right, immemorial custom, organic communitarian norms, divine will, and so forth. ${ }^{17}$

Third, the blurring of institutional lines between the state and the family is more obvious than blurring along the market/ family or market/state boundaries. It has been common forever to speak of the public functions of the family in producing and socializing "the next generation." Using this and other rationales, the state attempts to determine the content of and then enforce performance of familial roles, both of parents and children. Modern statutory schemes authorize social welfare agencies backed by courts to intervene on no more precise grounds than "the best interests of the child" or the child's "need for supervision." It often seems that the legislator sees parents as a mere adjunct or subagency of the state. ${ }^{18}$

Finally and paradoxically, when people are speaking and thinking of the economy, or "world of work," as the "public sphere," they tend to lump politics, religion and sexuality together as an opposed sphere, into which an employer (for example) has no business intruding. In this perspective, what life in the state has in

16 See J. Buchanan \& G. Tullock, The Calculus of Consent: Locical Foundations of Constitutional Democracy (1962); Economics of the Famity (T. Schultz ed. 1974).

17 See J. Demos, A Littue Commonwealth: Fammy Life in Plymouth Colony (1970); Kennedy, supra note 1, at 294-311, 346-50; K. Marx, Economic and Philosophical Manuscripts, in EARLX Wrarings 154 (T. Bottomore ed. 1964); S. Firestone, The Dialectic of Sex (1970); MacKinnon, Feminism, Marxism, Method, and the State: An Agenda for Theory, 7 Signs 515 (1982).

18 See J. Donzelot, The Polueing of Famines (R. Hurley trans. 1979); Katz \& Teitelbaum, PINS Jurisdiction, the Vagueness Doctrine, and the. Rule of Law, 53 IND. L.J. 1 ( 1977 ). 
common with life in the family is that both are quintessentially private. ${ }^{10}$

Following out these lines of similarity and difference, one simply loses one's ability to take the public/private distinction seriously as a description, as an explanation, or as a justification of anything.

\section{Conclusion}

The American Bar Foundation should commission an empirical study of the decline of the liberal distinctions, in the hope of giving precise definition to the stages of decline and establishing whether they occur in an invariant sequence. The history of the demise of liberal legalism is too important to leave to guesswork.

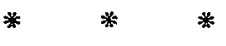

${ }^{19}$ Cf. K. Marx, On the Jewish Question, in EARLY WrItring, supra note 17, at 1. 